\title{
Decarbonisation of operations management - looking back, moving forward: a review and implications for the production research community
}

Ana Beatriz Lopes de Sousa Jabbour, Charbel Jose Chiappetta Jabbour, Joseph Sarkis, Angappa Gunasekaran, Marcelo Wilson Furlan Matos Alves \& Daniela Andriani Ribeiro

To cite this article: Ana Beatriz Lopes de Sousa Jabbour, Charbel Jose Chiappetta Jabbour, Joseph Sarkis, Angappa Gunasekaran, Marcelo Wilson Furlan Matos Alves \& Daniela Andriani Ribeiro (2018): Decarbonisation of operations management - looking back, moving forward: a review and implications for the production research community, International Journal of Production Research, DOI: 10.1080/00207543.2017.1421790

To link to this article: https://doi.org/10.1080/00207543.2017.1421790

曲 Published online: 16 Jan 2018.

Submit your article to this journal $\pi$

Џ Article views: 182

View Crossmark data $\nearrow$

Citing articles: 1 View citing articles $\llbracket$ 


\title{
Decarbonisation of operations management - looking back, moving forward: a review and implications for the production research community
}

\author{
Ana Beatriz Lopes de Sousa Jabbour ${ }^{\mathrm{a}}$, Charbel Jose Chiappetta Jabbour ${ }^{\mathrm{a} *}$, Joseph Sarkis ${ }^{\mathrm{b}}$, Angappa Gunasekaran ${ }^{\mathrm{c}}$, \\ Marcelo Wilson Furlan Matos Alves ${ }^{\mathrm{d}}$ and Daniela Andriani Ribeiro ${ }^{\mathrm{d}}$
${ }^{a}$ Montpellier Business School, Montpellier Research in Management, Montpellier, France; ${ }^{b}$ Foisie Business School, Worcester Polytechnic Institute, Worcester, MA, USA; ${ }^{c}$ California State University, Bakersfield, CA, USA; ${ }^{d}$ Department of Production \\ Engineering, UNESP-São Paulo State University, Bauru, Brazil
}

(Received 1 September 2017; accepted 18 December 2017)

\begin{abstract}
This paper systematically analyses the vital motivations, drivers and barriers to the adoption of low-carbon operations management practices in response to climate change, highlighting the implications for the International Journal of Production Research (IJPR)'s community, which has contributed significantly to discussion of and research into sustainable production. Based on a thorough review of key articles on low-carbon operations management published in a number of prestigious journals, seven propositions for future research are suggested. Additionally, a unique classification of the barriers to and motivations for low-carbon production is put forward. These areas, which deserve further investigation, are (a) economic issues, (b) policy, (c) technology, (d) governance and (e) the market. The research agenda proposed for low-carbon production and operations may prove useful to the production research community in planning future developments and research projects, increasing knowledge and designing teaching modules on the topic. The study concludes by shedding light on the main research opportunities that IJPR's community will encounter.
\end{abstract}

Keywords: sustainable production; sustainable industrial engineering; low-carbon economy; sustainable operations management; sustainable supply chain; climate change

\section{Introduction}

In this research, factors that are considered motivators and barriers to the adoption of low-carbon production management practices are identified, classified and analysed. In the process, light is shed on the implications for the IJPR community in terms of scope for future research, teaching and the advancement of knowledge. This work addresses recent calls from the IJPR community for more research into emerging and complex sustainable production topics (Sarkis and Zhu 2017).

Over the past 55 years, the IJPR has contributed to the debate on sustainable production (Sarkis and Zhu 2017), and particularly to expanding understanding of low-carbon production and operations. The IJPR has contributed knowledge on low-carbon manufacturing (for example, Chen and Hao 2015; Dhavale and Sarkis 2015; Liu et al. 2015; Wang and Choi 2016), low-carbon logistics and supply chains (such as Validi, Bhattacharya, and Byrne 2014; Brandenburg 2015; Du et al. 2015a) and low-carbon products (Tang, Wang, and Ullah 2017). However, by looking back at key articles in the field of low-carbon production and operations, we believe the IJPR can move the sustainability debate forward, furthering its already significant contribution to a more sustainable society.

Overall, the global discussion and analysis of business responses to climate change are still underdeveloped. This is because climate change issues are multifaceted and include varied elements, such as human security, food security, natural disasters, poverty (Leichenko and Silva 2014), economic crises, health issues and use of land. However, the consensus is that negative consequences of climate change have become more frequent (Rosen and Guenther 2015).

Climate change exposes people, societies and economic sectors to risks such as extreme weather events, natural disasters and economic and social vulnerability (IPCC 2014). According to the World Business Council for Sustainable Development (WBCSD 2008), organisations play an important role in inducing changes in patterns of consumption and production; consequently, they can contribute to the mitigation of greenhouse gas emissions, or decarbonisation (Nakićenović 1996).

\footnotetext{
*Corresponding author. Email: cjcjabbour@gmail.com 
The Intergovernmental Panel on Climate Change (IPCC) has suggested certain practices that industries can adopt to mitigate emissions contributing to the greenhouse effect, such as improving energy efficiency in new processes and technologies, promoting efficient materials and products, and recycling (IPCC 2014). These activities can be understood and implemented by organisations through low-carbon operations management. According to Böttcher and Müller (2015), low-carbon operations entail the integration of carbon efficiency in planning, execution and control of business processes. For Du et al. (2015), low-carbon operation involves a number of factors, such as product design, manufacturing processes and production equipment, as well as transport and packaging, in order to minimise carbon emissions and energy consumption.

In 2013, the Carbon Disclosure Programme (CDP) conducted a survey among the member companies of its supply chain programme. This revealed that around $30 \%$ of responding companies had set carbon reduction targets (CDP 2014). McKinsey's (2012) research on sustainability included a survey of CEOs from different sectors and countries and found that about $45 \%$ of respondents considered sustainability a priority. However, it was not among the top three most important issues. Another finding of this research was that $46 \%$ of respondents' companies manage sustainability somewhat.

Taking the above into consideration, the research question of the present article is: What are the motivations and barriers that could inhibit companies' adoption of low-carbon operation management practices? Biesbroek et al. (2013) assert that the study of barriers is important because without understanding barriers it is difficult to develop strategies to overcome them. They also claim that this theme is fragmented throughout the literature, necessitating a review of the literature. This paper seeks to integrate these approaches through the identification of motivations and barriers to the adoption of low-carbon operation management practices in order to propose a conceptual framework. This conceptual framework will be useful for the production research community, and particularly for stakeholders of the IJPR.

This research aims to contribute to the literature in three ways: (a) by organising the variables (Sections 4 and 5) to analyse the motivations, drivers and barriers to the adoption of low-carbon operation management practices in response to climate change; (b) by proposing a future research agenda (Section 5) arising from the systematisation of the papers identified in the research; and (c) by delving into the potential implications of the proposed research agenda for the IJPR community on sustainable production and low-carbon operations (Section 6).

\section{Brief conceptual foundation}

Carbon emission management has become an issue within organisational decision-making (Gasbarro and Pinkse 2016) due to the debate on climate change which has been taking place in the global community in recent decades (UNFCCC 2015a).

The adoption of low-carbon operations management practices can turn efficient carbon emission management into a reality. According to Böttcher and Müller (2015), low-carbon operations entail the integration of carbon efficiency in the planning, execution and management of business processes. These authors state that there are three areas within low-carbon operations:

(a) Low-carbon products: According to Tang and Zhou (2012), product design is an important instrument for sustainable development. For Lee (2012), the reduction of products' carbon emissions is based on the development of more energy-efficient products and lowering the environmental impact throughout a product's life cycle.

(b) Low-carbon production and processes: According to Lee (2012), low-carbon production includes the development of energy efficiency projects, replacing existing energy sources with cleaner fuels and reducing the direct emission of greenhouse gases by means of input exchange. This area also includes the development of carbon inventory.

(c) Low-carbon logistics: According to Tang and Zhou (2012), transport activity is one of the largest sources of atmospheric emissions due to fossil fuel consumption. According to Dey, Laguardia, and Srinivasan (2011), logistics managers can reassess, for example, the mode of transport used in order to minimise their carbon footprint, as well as optimising routes and shipping schedules (Norlund and Gribkovskaia 2013; Pan, Ballot, and Fontane 2013; Islam and Olsen 2014; Handler et al. 2014).

However, organisations may be restricted in their access to fuels, energy sources and water (Busch and Hoffmann 2007; Gasbarro, Rizzi, and Frey 2014), or have to deal with climate regulations that impact on the acquisition of technologies and obtaining services from the market (Aben, Hartley, and Wilkening 2010; Hitchcock 2012; Plambeck 2012; Okereke and Küng 2013). As a result, organisations may face barriers, drivers and/or motivators when adopting low-carbon operational practices. 
Barriers may appear in both the development and the implementation of organisational strategies to adapt to climate change (Biesbroek et al. 2013). Eisenack et al. $(2014,868)$ define a barrier as 'an impediment to specified adaptations for specified actors in their given context that arise from a condition or set of conditions'. According to the IPCC (2014), barriers are factors that make it difficult to plan and implement adaptations, including lack of resources such as technology, knowledge and finances. Investigating these factors is important because barriers can significantly reduce the range of options and opportunities available to organisations to adapt to the impacts of climate change (IPCC 2014). Additionally, many barriers make adaptation less efficient or effective, and may require costly changes that lead to loss of opportunities or higher costs for organisations (Moser and Ekstrom 2010). Understanding the nature of barriers to the adoption of low-carbon operations management practices bolsters comprehension of the reasons why companies take certain actions (Chu and Schroeder 2010), making it possible to outline the best strategic actions to deal with these barriers (Biesbroek et al. 2013; Eisenack et al. 2014).

Okereke $(2007,479)$ defines motivation as a factor which 'arise[s] more or less directly from the raison d'etre of business to maximise profit (...) motivational factors on their own are capable of inciting corporations to undertake carbon management actions'. Drivers, on the other hand, are 'the factors that have the potential to "force" corporations to take climate response action even when they would not have ordinarily wanted to do so' (Okereke 2007, 479). Studies identifying low-carbon operation management drivers offer insights into the development of strategic policies, understanding the susceptibility of organisations - in terms of stimulus and incentives - and in turn how to develop incentives (Salon, Murphy, and Sciara 2014).

Climate change has become a risk to businesses due to its potential to cause disruption and vulnerability in the production chain (Winn et al. 2011). In this context, developing resilient organisational capabilities is crucial. Organisational resilience refers to the ability of an organisation to deal with unpredictable events, and to respond to demand as usual based on strategic and operational expertise (Annarelli and Nonino 2016). Therefore, identifying motivations, drivers and barriers is relevant to developing organisational resilience in order to combat the harmful consequences of climate change.

\section{Research procedures}

\subsection{Search for articles}

The articles selected in this study were accessed using the SCOPUS database. SCOPUS carries over 20,000 periodicals from more than 5000 publishers and boasts in excess of 49 million registered users. This database is also considered the world's most peer-reviewed database (Dangelico 2016), forming the largest body of research in the fields of science, technology, medicine, social sciences, the arts and humanities (Fahimnia, Sarkis, and Davarzani 2015).

Keywords were chosen in advance and arranged according to the scope of the research (Tranfield, Denyer, and Smart 2003). The selection of keywords was underpinned by an exploratory search for seminal articles in the field of climate change and low-carbon research within the corporate context. The method used with these keywords was based on the studies of Jabbour (2013), Mariano, Sobreiro, and Rebelatto (2015) and Dubey et al. (2017). The keywords were as follows:

- (Barriers OR Limitations OR Difficulties OR Obstacles OR Impediments) and, after receiving the search returns, filtered by ('Low Carbon' OR 'Carbon Management' OR 'Carbon Emission');

- (Incentives OR Motivations OR Drivers OR Enablers) and, after receiving the search returns, filtered by ('Low Carbon' OR 'Carbon Management' OR 'Carbon Emission');

- (Barriers OR Limitations OR Difficulties OR Impediments OR Drivers OR Motivations OR Enablers) AND 'environmental strategy' and upon receiving the search returns, filtered by 'carbon';

- (Barriers OR Limitations OR Difficulties OR Impediments OR Drivers OR Motivations OR Enablers) AND 'environmental management' and upon receiving the search returns, filtered by 'carbon';

- (Barriers OR Limitations OR Difficulties OR Impediments OR Drivers OR Motivations OR Enablers) AND 'green' and upon receiving the search returns, filtered by 'carbon';

- (Barriers OR Drivers) AND (Low Carbon OR Carbon Emission OR Greenhouse Gas) AND (Corporate OR Business OR Management OR Operations OR Organisations OR Strategy).

\subsection{Selection of articles}

The number of articles returned from the above searches was 5380 (books, book chapters and conference papers were excluded). To refine this number during the selection stage, three researchers involved in this study routinely gathered 
to debate the inclusion and exclusion of articles, taking into consideration the scope and aim of this article (Tranfield, Denyer, and Smart 2003). Many papers were excluded during the selection process due to their fields of study (chemistry, physics, biology, medicine, etc.), and duplicate articles that appeared more than once via different keyword combinations were excluded. After debating inclusion and exclusion, the titles and abstracts of the remaining papers were read and those suitable for the study were selected. At the end of this screening process, the result was that 270 articles were found likely to be suitable. For these articles, the researchers performed in-depth analyses of the content, selecting those relevant to this article. After thorough reading, it was noted that the content of some papers was not fully suited to the proposed scope. Thus, at the end of the selection process, 58 articles were selected for systematic analysis.

\subsection{Data extraction from articles}

A number of categories of analyses (Table 1) were put forward in order to systematise information from the selected articles. The following categories were chosen:

- Context (Country): (a) developed country or (b) developing country. According to Luo, Tang, and Lan (2013), developing countries are unwilling to disclose information about their carbon-mitigation activities compared to developed countries. Therefore, it seems to be important to divide the analysis by geographical context.

- Economic sector: (a) public, (b) multinational or (c) non-multinational. There is a discussion around how cities and regions can promote actions to mitigate greenhouse gas emissions. Therefore, it would be interesting to explore the different perspectives between the public and private sectors; the private sector is further divided into multinational and non-multinational organisations.

- Article's objective: content analysis was performed for this category. This assessment was qualitative and not based on codes. As a result, this variable was not included in Table 1.

- Research method: (a) qualitative, (b) quantitative, (c) mixed method or (d) theoretical. From this analysis, it is possible to suggest future research.

- Participation in a voluntary low-carbon programme: (a) yes or (b) No. Companies with a propensity to disclose information on emissions targets may have more ongoing initiatives to mitigate climate change.

- Low-carbon operations practice: (a) product, (b) process, (c) logistics or (d) not specified. This classification is based on Böttcher and Müller (2015).

- Organisational theories: (a) one theory was used, (b) two, (c) more than two theories were used or (d) no theory was used. In general, organisational theories can be applied to understanding production research problems (Dubey et al. 2017). Organisational theories support explanations for and descriptions of organisational behaviours and structures (Sarkis, Zhu, and Lai 2011), so their use may explain factors considered motivators and barriers to climate-change strategies.

Table 1. Categories of analyses to systematise information from the articles.

\begin{tabular}{|c|c|c|}
\hline \multirow{2}{*}{$\begin{array}{l}\text { Meaning } \\
\text { Context (Country) }\end{array}$} & \multicolumn{2}{|c|}{ Codes for alternatives } \\
\hline & $\begin{array}{l}1 \mathrm{~A} \\
1 \mathrm{~B}\end{array}$ & $\begin{array}{l}\text { Developed } \\
\text { Developing }\end{array}$ \\
\hline \multirow[t]{3}{*}{ Economic sector } & $2 \mathrm{~A}$ & Public \\
\hline & $2 \mathrm{~B}$ & Multinational \\
\hline & $2 \mathrm{C}$ & Non-Multinational \\
\hline \multirow[t]{4}{*}{ Research method } & $3 \mathrm{~A}$ & Qualitative \\
\hline & $3 \mathrm{~B}$ & Quantitative \\
\hline & $3 \mathrm{C}$ & Mixed Method \\
\hline & $3 \mathrm{D}$ & Theoretical \\
\hline \multirow[t]{2}{*}{ Participation in voluntary programme } & $4 \mathrm{~A}$ & Yes \\
\hline & $4 \mathrm{~B}$ & No \\
\hline \multirow[t]{4}{*}{ Low-carbon Operations management practices } & $5 \mathrm{~A}$ & Product \\
\hline & $5 \mathrm{~B}$ & Process \\
\hline & $5 \mathrm{C}$ & Logistics \\
\hline & $5 \mathrm{D}$ & Not Specified \\
\hline \multirow[t]{4}{*}{ Organisational theories } & $6 \mathrm{~A}$ & One \\
\hline & $6 \mathrm{~B}$ & Two \\
\hline & $6 \mathrm{C}$ & More than Two \\
\hline & $6 \mathrm{D}$ & None \\
\hline
\end{tabular}

Notes: 'Article's objective' and 'Classification of the variables' were not included in Table 1 and, therefore, not coded. 
- Classification of the motivators, drivers and barriers: content analysis was performed for this category due to the myriad different aims that could be identified. This assessment was qualitative and not based on codes. Because of this, this variable was not included in Table 1.

Table 1 presents the categories of analyses and their respective codes.

The researchers of this article analysed the 58 selected articles based on Table 1. Each article was searched for data which matched the categories of analysis, and was then inserted into a single Excel datasheet for statistical data analyses. Taking into account that there were pre-established codes for organising data collection, it was assumed that the classification process was reliable and followed a consistent pattern between the researchers' analyses.

Analyses from descriptive statistics were developed based on frequency to highlight the general tendency of the results. Content analysis was conducted to gather the aims and the motivators, drivers and barriers of the articles searched. The combination of these analyses with arguments from literature support the propositions put forward by the present article. This procedure is based on Biesbroek et al. (2013), who studied barriers to adaptation to climate change.

\section{Analyses of the published papers}

This section aims to present data drawn from the 58 articles selected through the process described. Systematised results have been organised by analysis category. We note that not all of the categories were coded.

\subsection{Context (Country)}

The first analysis category refers to the identification of the geographic/economic context reported in the articles studied. This category is divided into $1 \mathrm{~A}$ - Developed nations, and 1B - Developing nations. This distinction is important as barriers and motivators may differ from one organisation to another due to the context in which they operate (Liu 2014).

Around $57 \%$ of the articles reviewed reported studies that were conducted within the context of developed nations. Developing nations were analysed in about $34 \%$ of the articles; only $9 \%$ of the articles discussed both contexts. Figure 1 shows the data.

\subsection{Economic sector}

Category 2 considers the economic sectors studied in the articles. It is divided into 2A - Public, 2B - Multinational and $2 \mathrm{C}$ - Non-multinational. Different approaches were found to the economic sectors studied in the selected articles. However, all combinations permitted by this category were employed. That is: studies focused purely on the public sector (2A), solely on multinational organisations (2B), only on non-multinational organisations (2C), on the public sector and on multinationals $(2 \mathrm{~A}, 2 \mathrm{~B})$, on the public sector and non-multinationals $(2 \mathrm{~A}, 2 \mathrm{C})$, on multinationals and non-multinationals, contextualising only the private sector $(2 \mathrm{~B}, 2 \mathrm{C})$ and on all three economic sectors $(2 \mathrm{~A}, 2 \mathrm{~B}, 2 \mathrm{C})$.

The results showed that $30 \%$ of the articles looked at the three economic sectors simultaneously. Around $16 \%$ of the reviewed articles studied only the public sector. The majority of the articles looking only at private companies focused solely on non-multinational firms (30\%). Figure 2 presents the full data from this analysis category.

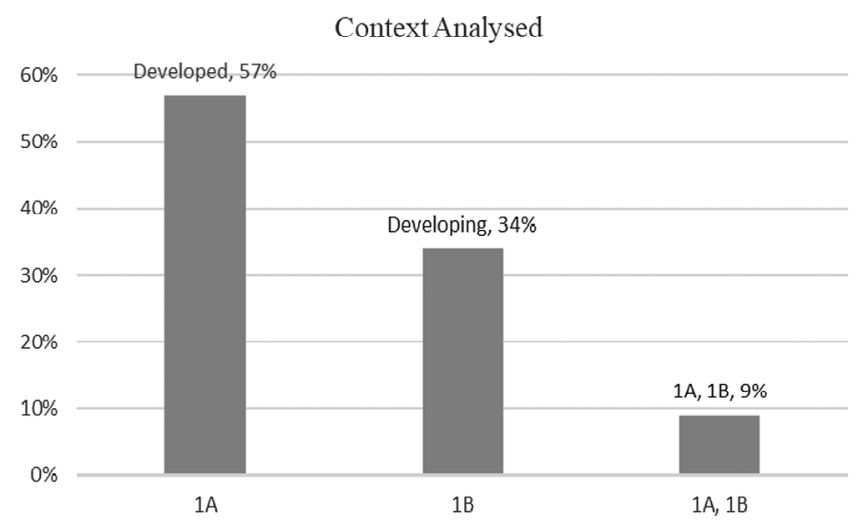

Figure 1. Frequency of analysed contexts (country). 


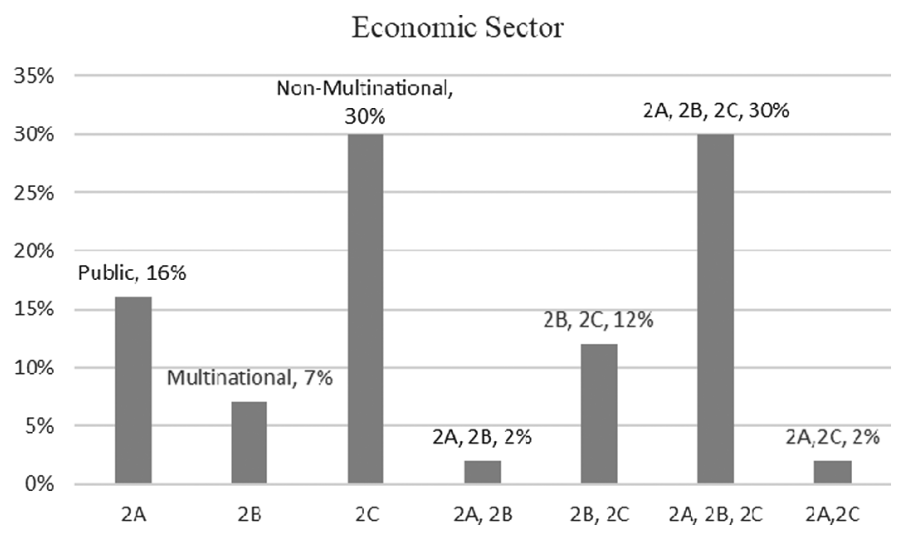

Figure 2. Frequency of economic sectors.

\subsection{Articles' objectives}

The list of the 58 selected articles is presented in Table 2, which provides a brief description of the systematised papers. Content analysis was used to comprehend, organise and group the aims of the 58 articles selected for review. By thus distinguishing areas of interest, motivators and barriers in the field of low-carbon operations management, it is possible to propose new avenues of study, validating this approach. The objectives identified in the content analysis are detailed below; the results are based on objectives or topics which are cited more than once since topics cited only once tend to signal sporadic research:

- Identifying and discussing barriers (and motivators) for mitigating $\mathrm{CO}_{2}$ in a given sector or region/country (29\% of papers);

- Identifying and discussing incentives for the control and reduction of $\mathrm{CO}_{2}$ emissions in regions and cities $(19 \%$ of papers);

- Analysing barriers to the adoption of energy efficiency (12\% of papers);

- Discussing barriers of political and regulatory nature as inhibiting factors to reducing $\mathrm{CO}_{2}$ (9\% of papers);

- Understanding barriers to investment in infrastructure for clean energies (5\% of papers);

- Identifying and discussing barriers to voluntary reduction of gases that promote the greenhouse effect (3\% of papers);

- Understanding motivators for technological changes related to climate change ( $3 \%$ of papers);

- Analysing aspects of collaboration in supply chains to contribute to climate change strategies (3\% of papers);

- Discussing barriers to land use to reduce $\mathrm{CO}_{2}$ (3\% of papers).

\subsection{Research method}

Category 3 segmented the analysed papers according to the research method employed. As such, the segmentations were: 3A - Qualitative, 3B - Quantitative, 3C - Mixed method and 3D - Theoretical.

The selected papers most often employed the qualitative method, representing $38 \%$. The theoretical method was used by $26 \%$ of the selected sample, and the quantitative method by $22 \%$. The mixed method was used by $14 \%$ of the studied papers. Figure 3 details the above-mentioned information.

\subsection{Participation in voluntary programmes}

There are certain organisations that tend to participate in voluntary carbon disclosure projects. This category aims to identify which papers studied organisations that voluntarily participate (4A) or do not (4B) in these types of programmes. It was shown that $86 \%$ of the papers did not have, or chose not to, access databases linked to these voluntary programmes to collect data about organisations. Figure 4 presents the percentages relative to this analysis category. 
Table 2. Brief description of the papers reviewed.

Article

St-Laurent, Hagerman, and Hoberg (2017)

Meyers et al. (2016)

De Wolf, Pomponi, and Moncaster (2017)

Long, Blok, and Coninx (2016)

Meath, Linnenluecke, and Griffiths (2016)

Henriques and Catarino (2016)

Polzin (2017)

Kragt, Dumbrell, and Blackmore (2017)

Masud et al. (2017)

He et al. (2017)

Herrmann and Guenther (2017)

Santos (2017)

Yi, Feiock, and Berry (2017)

Reyers, Gouws, and Blignaut (2011)

Lee et al. (2013)

Lo (2010)

Aben, Hartley, and Wilkening (2010)

Zhu and Geng (2013)

Lee (2015)

Galbreath (2014)

Jeswani, Wehrmeyer, and Mulugetta (2008)

Okereke and Küng (2013)

Jaber and Probert (2001)

Chu and Schroeder (2010)
Brief summary

The authors reported the main barriers to carbon offsets in Canadian forests based on a qualitative study conducted with stakeholders in the sector

The article identified barriers faced by small- and medium-sized companies in the Food and Drink sector located in European countries in improving energy efficiency, and provided recommendations

The authors identified drivers and barriers to low-carbon processes in the building sector in developed countries

The article identified barriers to the adoption of smart technologies for reducing carbon emissions in the agriculture sector in European countries

The authors analysed barriers and motivations for small- and medium-sized companies participating in voluntary programmes for energy efficiency in Australia

The article found and discussed barriers to pursuing energy efficiency in small- and mediumsized enterprises in Portugal in order to reduce carbon emissions, and proposed ways to overcome the identified barriers

The article analysed challenges to clean technologies used in addressing low-carbon processes The authors identified the key drivers and barriers to engagement with carbon farming in the Australian agriculture sector

The article analysed the perception of climate change risks by farmers in Malaysia and the consequent barriers to adaptation strategies

The article discussed barriers to developing low-carbon logistics strategies in China

The authors proposed a scale of organisational barriers to understanding enterprises' climate change strategies in Germany

The author discussed macroeconomic barriers to decarbonisation of the transport sector

The authors developed a framework for understanding the reasons why cities in the USA have voluntarily adopted climate change policies

This study analysed the motivating factors behind voluntary climate change mitigation. Three factors were cited as important: legitimacy, financial business and moral responsibility

It was noted that the success of $\mathrm{CO}_{2}$ reduction in sectors such as electricity, heat production and transport in the region of Southeast Asia depends on a reduction in the differences and deficiencies in policies and regulations between ASEAN nations

Companies from the Taiwanese electronic sector have adapted to environmental trade barriers from international associations and sustainable procurement policies from customers to voluntarily reduce greenhouse gas emissions

This study sought to understand motivators and determine factors for technological changes related to climate change in the Canadian timber industry. The results found related to carbon neutrality, customer demands and corporate responsibility

The study demonstrated how extended supply chain practices contributed to attaining energy efficiency and carbon reduction goals in Chinese companies. It was noted that barriers such as financial gain, resources and capability are the leading obstacles to effectiveness and efficiency in companies

Economic and organisational factors were pointed out as having an impact on the adoption of energy-efficient practices in the steel industry in South Korea, where the government exerts an extensive amount of pressure on the sector to reduce carbon emissions

While climate change is a source of study due to the damage it causes, wine companies in Australia have noted that it may be good for planting and harvesting grapes. Despite this, climate change adaptations and mitigations present dilemmas due to the carbon price scheme, economic barriers and lack of market demand

Carbon restrictions imposed by governments do not ensure that $\mathrm{CO}_{2}$ reduction initiatives are standardised around the world. Barriers such as high costs, lack of financial resources and a lack of awareness, among others, are different in terms of $\mathrm{CO}_{2}$ reduction policies in the energy sectors of the UK and Pakistan

European regulations and competitive dynamics are factors that affect carbon management in the cement industry. Managers from four companies reported that unsuitable and unfavourable regulatory structures are the leading barriers to the sector attaining greater $\mathrm{CO}_{2}$ reductions $\mathrm{CO}_{2}$ mitigation in the electric sector in Jordan is considered a huge opportunity for the country. However, the sector faces obstacles to mitigating $\mathrm{CO}_{2}$. The barriers identified in this study include a lack of awareness, lenient energy price policies and a lack of access to technology This study, conducted with multiple stakeholders in Hong Kong, identified barriers related to reducing climate risks, such as costs, market competitiveness and a lack of expertise, among others. The motivators were reputation, risk reduction, and consistency in ethical values, among others 
Table 2. (Continued)

Article Brief summary

Salon, Murphy, and Sciara (2014)

Fleiter et al. (2012)

Urge-Vorsatz et al. (2009)

Dulal, Brodnig, and Shah (2011)

Boiral, Henri, and Talbot (2012)

Okereke (2007)

Pasquini, Cowling, and Ziervogel (2013)

Herbohn, Dargusch, and Herbohn (2012)

Carlsson-Kanyama, Carlsen, and Dreborg (2013)

Pitt and Randolph (2009)

Pålsson and Kovács (2014)

Lemieux et al. (2013)

Liu, Liu, and Sun (2011)

Chomaitong and Perera (2014)

Liu (2012)

Zhang and Wang (2014)

Wong, Ng, and Shahidi (2013)

Dilling and Failey (2013)

Sentance (2009)

Sullivan (2009)
Identified motivators and barriers to the public management of emission reductions in cities and counties in the United States

The study concluded that despite an energy efficiency audit programme which was successfully implemented in Germany, and the fact that some energy efficiency barriers had been overcome, financial barriers continued to impact small- and medium-sized companies

This study emphasised the potential to reduce emissions in the construction sector; however, economic barriers represent $20 \%$ of the costs of energy efficiency projects for a $10-15 \%$ energy reduction

The paper assessed physical, financial, social, human and natural barriers to the mitigation of carbon emissions in agriculture. The authors argued that the removal of barriers would lead to farmers collaborating in carbon mitigation initiatives

The results confirmed that the relation between environmental commitment and economic motivation is positive and has contributed to companies making use of greenhouse gas reductions to obtain other financial benefits

The paper looked at 100 companies in the United Kingdom and the motivators and barriers to their adoption of carbon management strategies

This study investigated the barriers to climate change adaptation in eight municipalities of South Africa. The barriers faced by public officials within this context relate to the municipality's ability to react to these issues, a lack of knowledge of the adaptation options, problems with the adopted policies and a lack of interest in climate issues

The paper analysed responses from public and private organisations in Australia concerning climate change policies and the main reasons for their actions. Among the barriers which emerged were uncertainty about regulation and the carbon market, lack of expertise on regulation and a lack of resources (financial and personnel). The motivators for adhering to regulations were compliance with legal requirements, social responsibility, management of legal risks and identification of cost gains

The paper found that the degree of privatisation within Swedish municipalities and the lack of support from outside decision makers form the barriers identified in adapting to local climate change in the next $20-30$ years

The authors showed that due to fiscal, political and institutional conditions, besides actual barriers in the planning process, municipalities in the United States have difficulty in planning climate protection

Reducing $\mathrm{CO}_{2}$ emissions from freight transport in Swedish companies is motivated more by internal issues than external pressure from stakeholders. When the organisation has economic and image motivators, it is more likely to reduce $\mathrm{CO}_{2}$ emissions

A framework was proposed based on an Importance-Performance Analysis (IPA) to gauge the perceived degree of importance and performance by the managers of land agencies and resources in the United States in relation to the capacity to adapt to climate change. Contextual, informational, financial, human and institutional barriers from agencies complicate management and decision-making processes aimed at climate change

The paper explored the situation of energy structure and supply in China, raising questions about political, financial and technological barriers that complicate the rapid development of the low-carbon economy in China

The study addressed the most significant drivers and barriers to the implementation of practices that reduce carbon emissions in local government agencies in Thailand

The author presented a study focused on organisational awareness and behaviour in carbon management in China, as well as the barriers in reducing carbon in their operations

The paper verified the methods of collaboration between companies in supply chains with the aim of reducing carbon emissions and identifying barriers and motivations behind this practice From the point of view of organisational culture, the paper examined the effect of drivers on the adoption of carbon reduction strategies. Rewards and more stringent standards are the leading drivers that bolster such strategies in Australian enterprises

Through a case study involving public and private land owners in the United States, the authors investigated the perception and implementation of carbon sequestration through the use of land, and what influence existing drivers and incentives have on decision-making

The goal of the paper was to study the leading challenges that the low-carbon society represents in the development of transport infrastructure in the United Kingdom. Based on a theoretical study, the author discusses the low-carbon society and issues regarding low-carbon transport Uncertainties in climate change policy were the main barrier for large European companies in adopting a more proactive approach to reducing their emissions 
Table 2. (Continued)

\begin{tabular}{|c|c|}
\hline Article & Brief summary \\
\hline Jongh and Möllmann (2014) & $\begin{array}{l}\text { The private sector in South Africa was studied in order to assess adhesion to voluntary } \\
\text { mechanisms for climate change mitigation and to identify market barriers that may prevent the } \\
\text { adoption of practices for this issue }\end{array}$ \\
\hline Eisenack et al. (2014) & $\begin{array}{l}\text { Authors discussed the main barriers encountered in the literature to organisational adaption } \\
\text { related to climate change, and the limitations of existing research on this issue }\end{array}$ \\
\hline Burch (2010) & $\begin{array}{l}\text { The paper proposed a typology of barriers that inhibit action on climate change in three } \\
\text { Canadian municipalities, exploring how these barriers influence the municipalities' capacity for } \\
\text { resilience in attaining greenhouse gas reductions and analysing the interaction and importance of } \\
\text { these barriers in these municipalities }\end{array}$ \\
\hline Ford et al. (2010) & $\begin{array}{l}\text { The authors conducted the study with the goal of understanding how climate change and its } \\
\text { risks are perceived, experienced and dealt with through mining industry practices in Canada }\end{array}$ \\
\hline Li et al. (2012) & $\begin{array}{l}\text { The paper aimed at studying the motivations and barriers faced in the implementation of } \mathrm{CO}_{2} \\
\text { capture-ready design on new-build coal-fired power plants in China }\end{array}$ \\
\hline Ng, Skitmore, and Cheung (2013) & $\begin{array}{l}\text { Interviews were conducted with construction project participants from Hong Kong to identify } \\
\text { practices employed and the drivers and barriers for the reduction of carbon emissions in the } \\
\text { construction industry. }\end{array}$ \\
\hline Liu (2014) & $\begin{array}{l}\text { A study of China was undertaken to identify, analyse and offer suggestions for overcoming } \\
\text { barriers faced in low-carbon production for industries with the highest energy consumption rates } \\
\text { in the country }\end{array}$ \\
\hline Jones (2015) & $\begin{array}{l}\text { The study investigated how institutional investors in the private sector perceive the barriers to } \\
\text { the expansion of investments in clean energy infrastructure and what political solutions may be } \\
\text { available for them }\end{array}$ \\
\hline Kavouridis and Koukouzas (2008) & $\begin{array}{l}\text { The paper assessed challenges and barriers to cleaner coal power, with a focus on carbon } \\
\text { storage and on technologies for capturing and storing carbon and increasing the political } \\
\text { measures necessary for emission trade. }\end{array}$ \\
\hline Pegels (2010) & $\begin{array}{l}\text { The work identified the theoretical barriers to investment in renewable energies in South Africa. } \\
\text { The main barrier identified is related to renewable energy technologies }\end{array}$ \\
\hline Giesekam et al. (2014) & $\begin{array}{l}\text { Barriers were identified in the use of materials that contain less carbon throughout supply chains } \\
\text { for the construction industry in the United Kingdom }\end{array}$ \\
\hline Garbuzova and Madlener (2012) & $\begin{array}{l}\text { The paper investigated the Joint Implementation and Green Investment Scheme as a possible } \\
\text { means of attracting foreign investment in transnational projects, providing capital for the } \\
\text { Russian energy sector with the goal of modernising operations, increasing energy efficiency and } \\
\text { reducing carbon emissions }\end{array}$ \\
\hline Tait, Laing, and Gray (2014) & $\begin{array}{l}\text { Barriers to the implementation of low-carbon transport initiatives were studied in Aberdeen City } \\
\text { Council, Scotland }\end{array}$ \\
\hline Lah (2015) & $\begin{array}{l}\text { The author highlighted the leading theoretical barriers to energy efficiency in the transport sector } \\
\text { in a number of countries around the world and suggested policies to overcome them }\end{array}$ \\
\hline
\end{tabular}

\subsection{Low-carbon operations management practices}

This category sought to identify which management practices for low-carbon operations are analysed in papers that discuss motivators and barriers to business strategies for climate change. The divisions of operational practices considered in this category were: Product - 5A, Process - 5B, Logistics - 5C, and Not-specified - 5D.

Around half of the selected papers, $53 \%$, did not specify which low-carbon operations management practices were being analysed. Among those which did specify, process was the most cited operational category among the reviewed papers, at $19 \%$. Figure 5 presents these data.

\subsection{Organisational theories}

This category aimed to identify which organisational theories contributed to the identification or interpretation of the effects of barriers and motivators in the adoption of low-carbon operations management practices. For this category, the number of theories used per paper was established, with $6 \mathrm{~A}$ representing one theory, $6 \mathrm{~B}$ two theories, $6 \mathrm{C}$ three or more theories and $6 \mathrm{D}$ representing none.

The great majority of the papers selected (90\%) did not present any theory as an analytical framework with which to discuss motivators and barriers to carbon management. Only six papers used a specific theory to analyse this subject. 


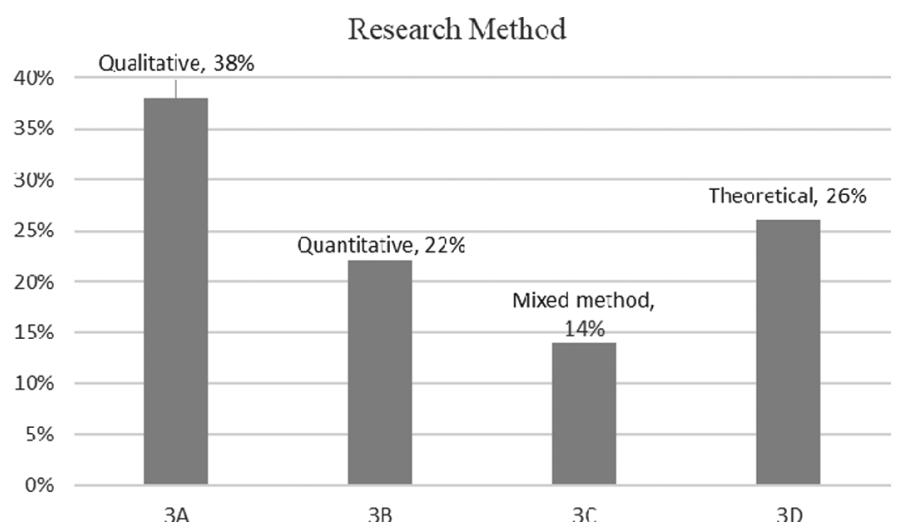

Figure 3. Frequency of research methods employed.

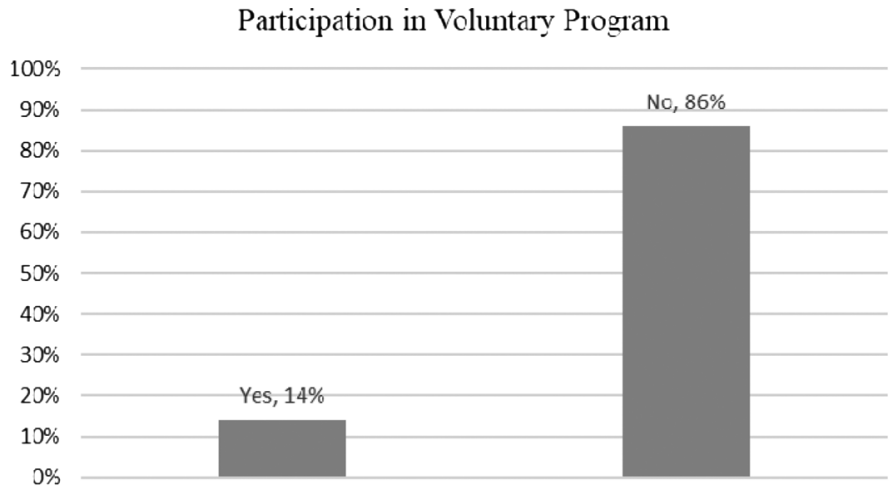

$4 \mathrm{~A}$

$4 B$

Figure 4. Frequency of voluntary participation in carbon disclosure programmes.

Low-Carbon Operations Practices

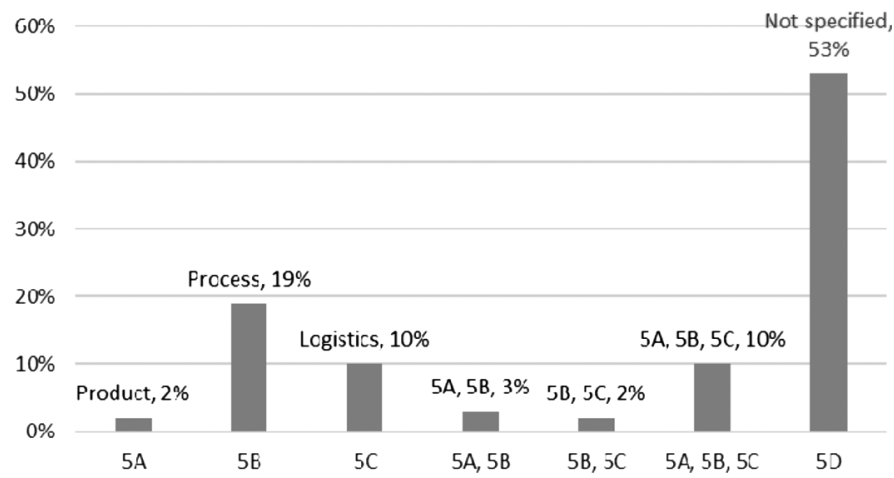

Figure 5. Frequency of low-carbon operations management practices.

The theories considered were: path dependence, evolutionary theory, induced technology change, institutional theory, resource-based view and the stakeholder theory, organisational learning and institutional collective (Aben, Hartley, and Wilkening 2010; Zhu and Geng 2013; Pålsson and Kovács 2014; Zhang and Wang 2014; Herrmann and Guenther 2017; Yi, Feiock, and Berry 2017). Figure 6 presents these data. 


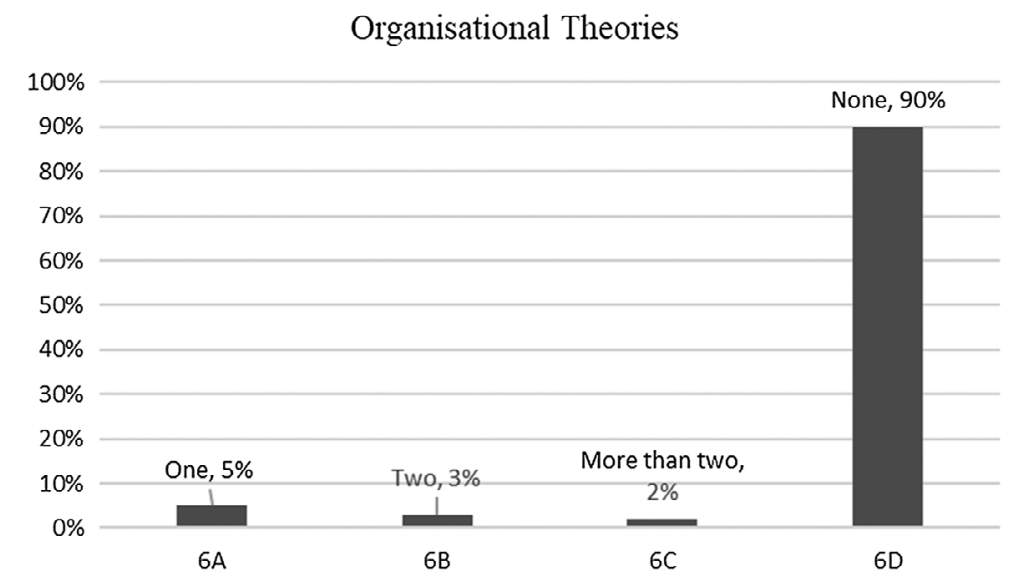

Figure 6. Frequency of organisational theories.

\subsection{Motivators, drivers and barriers}

The selected articles provided a wide spectrum of data related to barriers and motivators in the adoption of low-carbon operations practices. The survey identified over 160 types of barriers and motivators.

The identified barriers and/or motivators were either used for conducting empirical studies (Reyers, Gouws, and Blignaut 2011; Boiral, Henri, and Talbot 2012; Lee et al. 2013; Zhu and Geng 2013) or they were the findings of the research involved in the selected papers (Sullivan 2009; Aben, Hartley, and Wilkening 2010; Ford et al. 2010; Lo 2010; Lah 2015; Lee 2015). Additionally, it should be noted that the identified barriers and motivators may feature dual characteristics. For instance, the cost variable can be a barrier to low-carbon operations management as well as a motivator (cost reduction).

In the following section, a theoretical organisation is proposed for the variable motivators and barriers identified, in the form of clusters based on characteristics.

\section{Analyses and proposal of a research agenda}

The following section aims to analyse the findings from searches according to the above analysis categories and, emerging from this discussion, to propose future research in the field of low-carbon operations and its barriers and motivations.

\subsection{Context (Country)}

Studies looking at barriers and motivators of low-carbon operations management have considered the context of developed and developing countries at a ratio of 57\% and 34\%, respectively. Jeswani, Wehrmeyer, and Mulugetta (2008) note that low-carbon initiatives in developed countries have been backed by an international effort to reduce emissions of gases that lead to the greenhouse effect. These countries have prepared national policies aimed at preventing pollution and bolstering energy efficiency while also imposing emission restrictions. Developing countries, on the other hand, face additional challenges in emulating their developed counterparts, as their economic development policies may not align with the requirements of ecological modernisation. Luo, Tang, and Lan (2013) develop this idea by stating that organisations located in developing nations are less adept at promoting information about carbon mitigation activities. According to Gouvea, Kassicieh, and Montoya (2013), geographical factors are relevant both to understanding economic and political behaviour and to analysing how institutions - such as academia, industry and government - interact to manage natural resources in the context of the green or low-carbon economy. Geographical factors provide a perspective for understanding the role of institutions in promoting or reducing barriers and motivations for low-carbon management. Therefore, it would be interesting to see more research identifying, confronting and analysing how different national contexts tend to influence initiatives, the generation of barriers and the creation of motivating conditions for the adoption of low-carbon operations management practices. Accordingly, research proposal 1 could be:

- P1: To understand the effects of different national contexts in the adoption of low-carbon operations management practices and how these contexts tend to influence the creation or mitigation of barriers and motivators of these practices. 


\subsection{Economic sector}

There is a great deal of research looking at both private and public companies on the subject of barriers and motivators of low-carbon operations management. Non-multinational companies have been the subject of study more often than multinational firms. The objectives of studies focusing only on either multinational or non-multinational companies are generally quite similar, including identifying and discussing barriers and motivators of $\mathrm{CO}_{2}$ mitigation in a given sector, region or country and exploring barriers of a political and regulatory nature as inhibiting factors in reducing $\mathrm{CO}_{2}$. However, companies with experience in internationalisation tend to be more environmentally proactive (Aguilera-Caracuel, Hurtado-Torres, and Aragón-Correa 2012). Further, according to Zhu et al. (2011), foreign companies operating in China, for example, tend to be more active and prepared than Chinese companies in meeting environmental performance standards, as they are involved in global supply chains and respond to different environmental institutions. As such, research proposal 2 could be:

- P2: To analyse whether private multinationals tend to respond differently to the barriers and motivators of low-carbon operations management when compared to domestic companies.

\subsection{Article's objective}

Based on the content analysis performed and the results shown in Section 4, themes which were cited in more than 9\% of the articles analysed have been considered as tendencies of research objectives. Thus, four research themes were identified among the 58 papers selected:

- Identifying and discussing barriers and motivators for mitigating $\mathrm{CO}_{2}$ in a given sector, region or country $(29 \%$ of papers);

- Identifying and discussing incentives for the control and reduction of $\mathrm{CO}_{2}$ emission in regions and cities $(19 \%$ of papers);

- Analysing barriers to the adoption of energy efficiency practices ( $12 \%$ of papers);

- Discussing barriers of a political and regulatory nature as inhibiting factors in reducing $\mathrm{CO}_{2}$ (9\% of papers).

It is notable that barriers to low-carbon operations management have been prioritised; however, considering recent events, such as the agreements established at COP 21 (UNFCCC 2015b), there will certainly be opportunities to study motivators for the development of cleaner technologies, processes and products. Further, supply chains may reposition their activities and decide to collaborate in meeting agreements formed as a result of the developments at COP 21. Research proposal 3 would be:

- P3: To study the topic of business and climate change strategies from the perspective of motivations for the adoption of low-carbon operations practices, and to expand the scope of analysis towards supply chains.

\subsection{Research method}

It was noted that the papers analysed utilised primarily qualitative and theoretical methodologies. According to Eisenhardt (1989), qualitative studies and case studies, in particular, are recommended in situations in which, for example, a specific theme is still in the early phase of comprehension. This is therefore an indication that research in this field is still in an exploratory phase, in which constructs are not firmly established to a degree that allows for confirmatory tests and relation measurements (Forza 2002). This conclusion leads to research proposal 4:

- P4: The constructs of barriers and motivators of low-carbon operations management, taken from theoretical systematisation, should be used to expand empirical and quantitative studies, which will yield useful generalisations.

\subsection{Participation in voluntary carbon disclosure programmes}

Among the systematised papers, few of the companies investigated voluntarily publish their carbon reduction measurements. In general, companies participating in carbon disclosure do so due to social, market or stakeholder influence or international pressure (Gonzalez-Gonzalez and Ramirez 2016), or operate in sectors under greater social control due to higher emissions. In addition, there is a trend for companies with better performance to be more willing to participate in carbon disclosure (Peng, Sun, and Luo 2015). However, there may be bias in results deduced from research conducted only with companies that maintain and publish emission inventories. Thus, research proposal 5 would be: 
- P5: To compare the barriers and motivators faced in the adoption of management practices for low-carbon operations by both participating and non-participating companies in voluntary carbon disclosure programmes.

\subsection{Low-carbon operations management practices}

Product design and processing technology typically determine the types of pollutants emitted, the solid waste, potential dangers and the resources and energy consumed in manufacturing (Angell and Klassen 1999). According to Sarkis and Rasheed (1995), environmentally responsible manufacturing entails planning, development and the implementation of transformation and technology processes that minimise or eliminate waste. Furthermore, it aims to create recyclable products or those that can be remanufactured or reused. Jabbour (2010) states that, by means of product development activities, there is an increasingly clear consideration of the environmental dimension within production. Böttcher and Müller (2015) note that low-carbon products tend to improve competitiveness among organisations in the automotive industry due to the fact that the phase of use emits the most greenhouse gases.

Few of the selected papers that discussed barriers and motivators of low-carbon operations management mentioned any of these practices, whether product, process, or logistics. The most commonly cited practice was process due to debates on energy efficiency. Therefore, considering the relevance of environmentally responsible manufacturing, research proposal 6 is:

- P6: To discuss barriers and motivators for the adoption of low-carbon products and logistics practices.

\subsection{Organisational theories}

Using an organisational theory in the development of scientific research helps explain organisational behaviours, whether in relationships between organisations and their environments (internal and external), or among organisations (Sarkis, Zhu, and Lai 2011).

Only 6 out of the 58 papers reviewed considered the use of an organisational theory to provide grounds and arguments in the discussion of barriers and motivators of low-carbon operations management. Four particular theories may be suggested as being useful for the development of future research in this area. These theories are: institutional, ecological modernisation, stakeholders and the resource-based view (RBV). These have been suggested due to them being the most popular theories in the context of sustainability, and because they analyse relations between organisations and their environments.

Institutional theory considers that being situated within a greater organisational structure outside the organisation itself tends to generate certain types of social pressure (coercive, normative or mimetic) on organisations. This pressure can lead to changes in production and management systems in order to legitimise their actions, comply with regulations or imitate competition (Sarkis, Zhu, and Lai 2011; Touboulic and Walker 2015). According to Gouvea, Kassicieh, and Montoya (2013), there are multiple players in the institutional arena related to the green and low-carbon economies, such as the scientific community, providers of green products and services, green consumers and the public sector. Pressure of a coercive, normative or mimetic type may be a source of motivation leading to improved performance and, occasionally, the development of resources and capabilities, and each of the above players could assume a different role in the mediating process for putting pressure on companies to adopt low-carbon operations management practices.

Ecological modernisation theory (EMT) suggests that technological innovations and regulatory policies that encourage the prevention of pollution are a means to industrial and environmental development (Er, Mol, and Van Koppen 2012). Governmental policies can contribute to generating incentives and initiatives for clean production. Thus, they can be sources of motivators that lead to improvement in environmental performance and occasionally the development of resources and capabilities.

Stakeholder theory states that organisations generate external effects within their environments. Consequently, they should monitor the expectations of stakeholders who are directly impacted by their actions and decisions as such stakeholders tend to generate pressure on organisations (Sarkis, Zhu, and Lai 2011; Touboulic and Walker 2015). Stakeholders may be sources for the generation of barriers and motivators as they either collaborate or do not collaborate with organisations in seeking to meet their expectations concerning improved environmental performance.

The resource-based view theory centres on the perception that internal resources and capabilities are sources of sustainable competitive advantages and organisation profitability (Grant 1991; Hart and Dowell 2011). Examples of resources and capabilities are technologies, equipment, localisation and facilitated access to raw materials, training, 


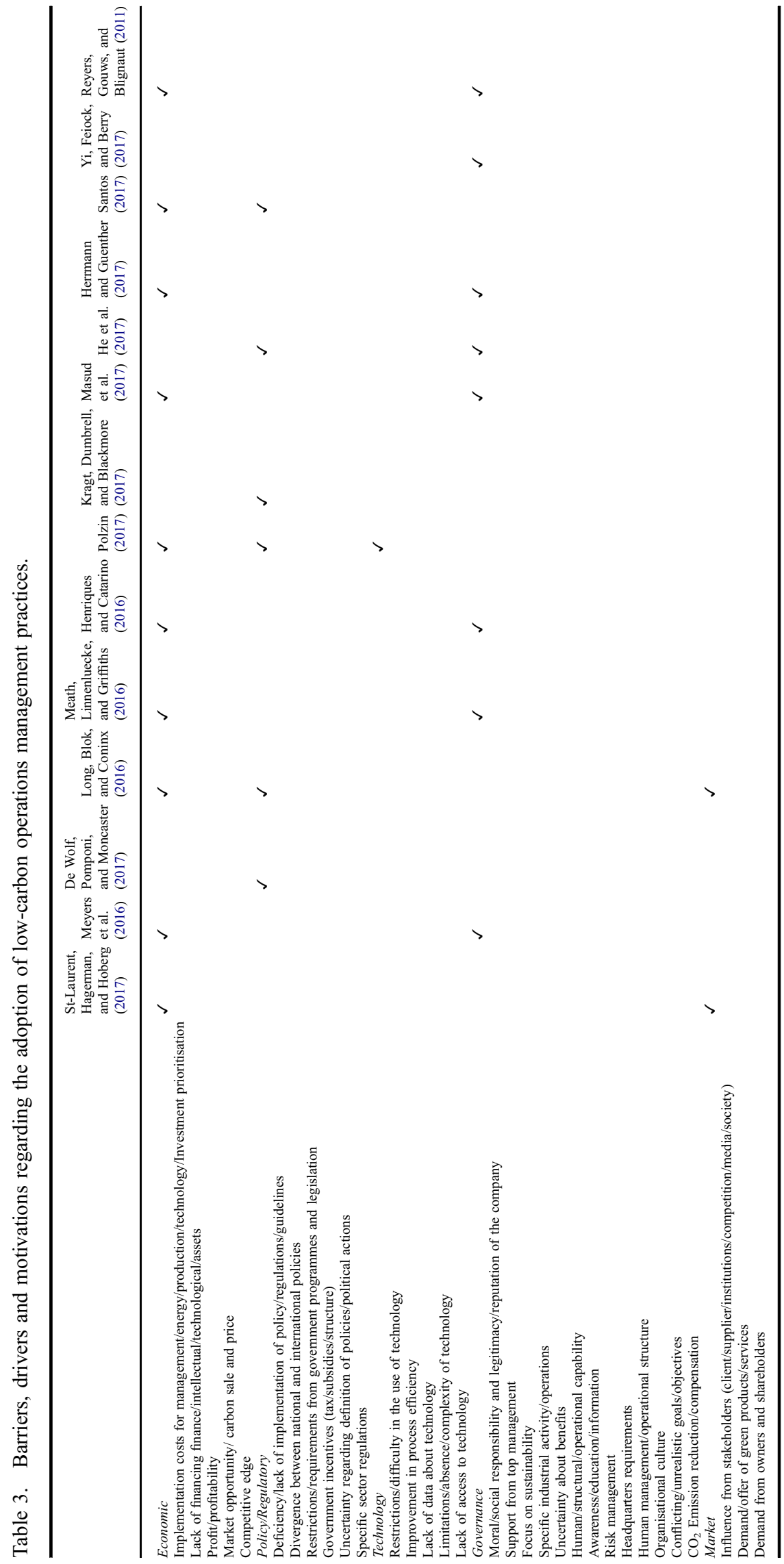

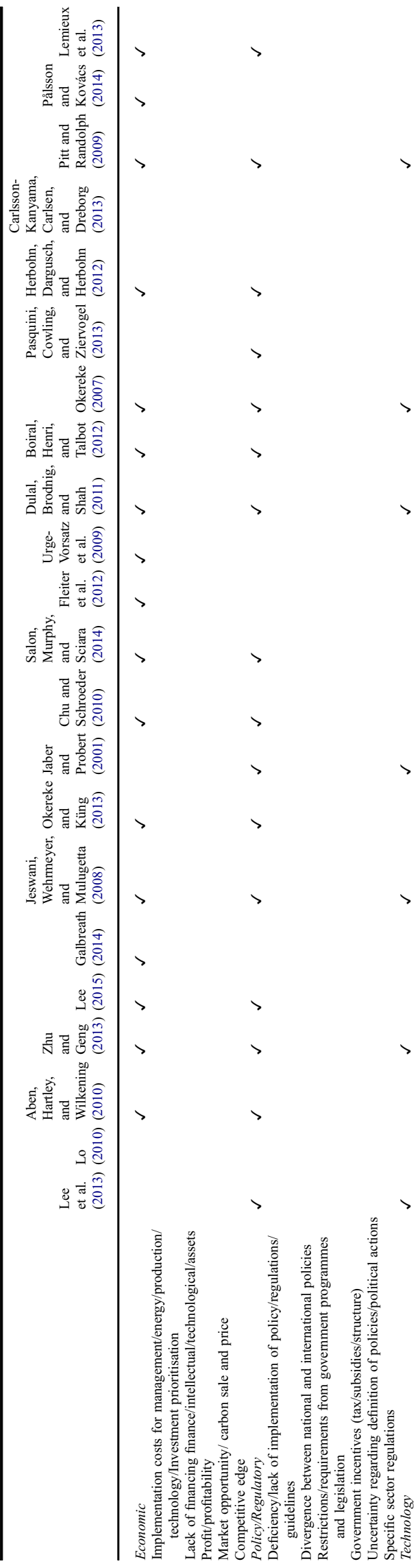




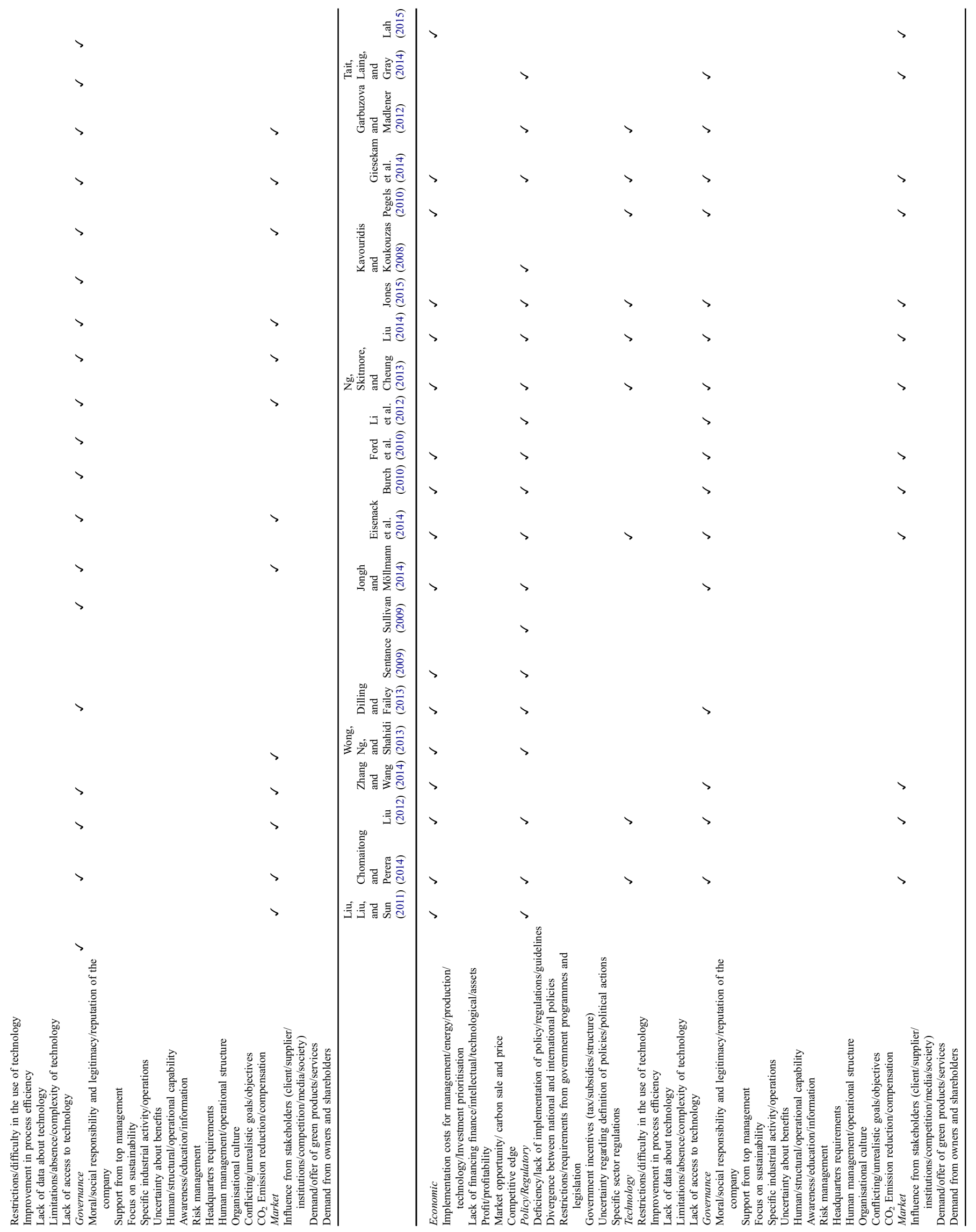


organisational learning and the development of relationships with different stakeholders (Barney 1991). Resources and capabilities may be sources of motivation, and barriers to climate change adaptations.

As a result, research proposal 7 is as follows:

- P7: To employ organisational theories as analysis methods to understand the motivators and barriers to low-carbon operations, these theories being: institutional theory, ecological modernisation theory, stakeholders theory and the resource-based view.

\subsection{Motivators, drivers and barriers}

The 58 articles were read by two researchers in order to find all relevant mentions of barriers, motivators and drivers for low-carbon operational practices. The information gathered resulted in a long list of variables - a total of 160 - for barriers, motivators and drivers. This result suggests that there is still a lack of unanimity in the literature, especially when taking into consideration that the majority of studies on the subject are theoretical or qualitative. Thus, this paper aims to establish factors to improve the grouping and comprehension of barrier and motivator variables.

Consequently, the list of variables was cognitively analysed to identify similarities and patterns among the variables, underpinned by Tranfield, Denyer, and Smart (2003), who state that the amount of information from a systematic review should be reduced in a concise and a summarised format. Thus, five factors were proposed for categorising the general meaning of the barriers, motivations and drivers for low-carbon operational practices. This proposal was developed by means of consensus building between the researchers. Additionally, each factor is composed of a group of variables drawn from the list initially generated by the researchers.

The factors proposed are: (a) economic, (b) political/regulatory, (c) technological, (d) governance and (e) market. The technological factor presented the fewest citations. A possible inference may be that technological factors are less relevant or restrictive in pursuing low-carbon operations management. Economic, political/regulatory and governance

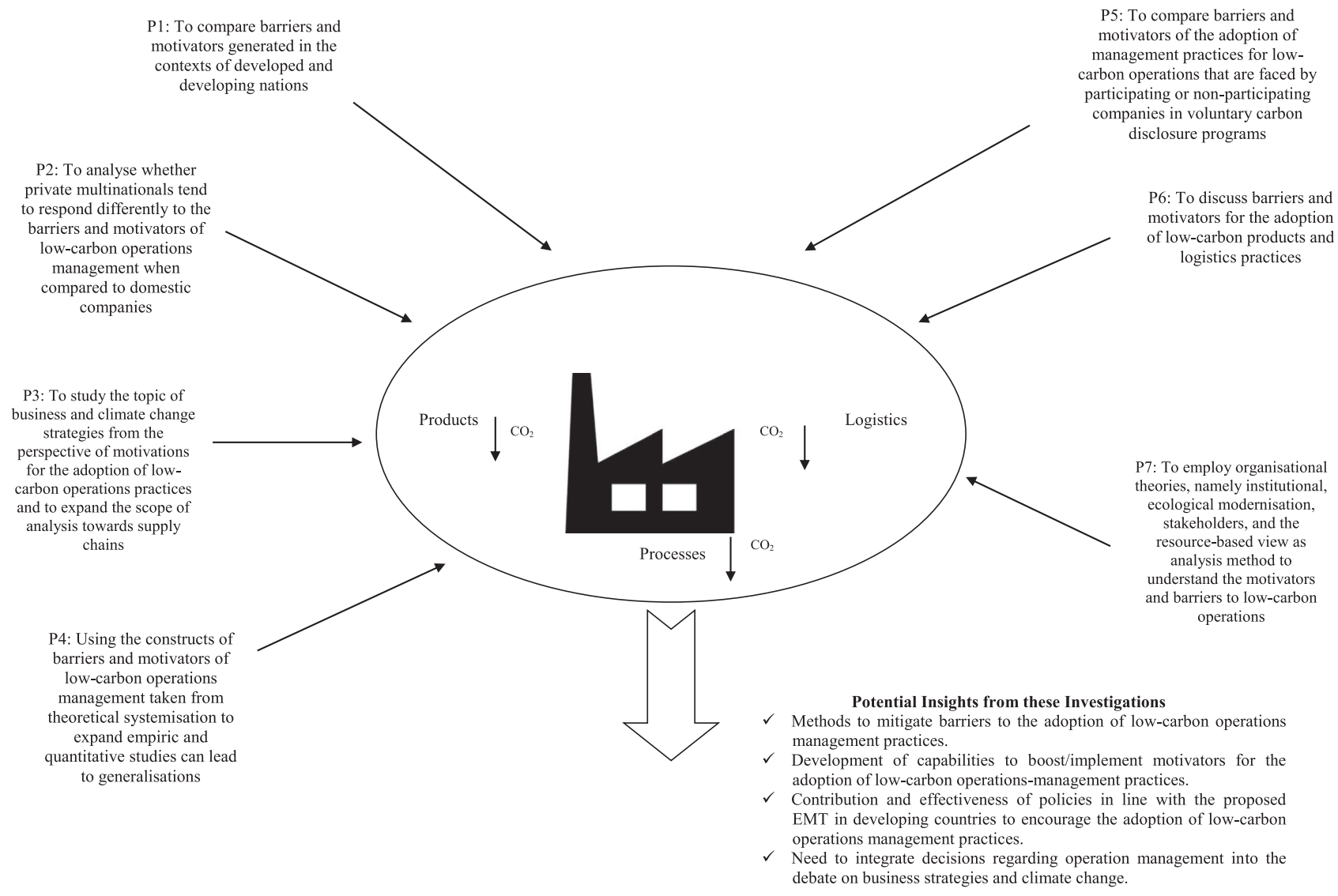

Figure 7. Research framework with opportunity for future studies. 
factors were cited equally often. It was thus understood that organisations need to deal with both external and internal aspects in order to follow low-carbon operations management. In other words, organisations must develop resources and capabilities to deal with pressure and uncertainty coming from the external environment.

Table 3 presents the factors and their respective variables based on the 58 articles systematised. There are marks in the table to represent which factors were cited by each systematised article. Marking all the variables mentioned for each article was avoided in order to provide an accessible visual aid to the table.

A framework (Figure 7) follows to summarise the research agenda derived from the theoretical systemisation proposed by this paper.

\section{Conclusion and implications for IJPR}

This research effort aimed to identify, classify and analyse the motivators and barriers to the adoption of low-carbon operations management practices, shedding light on potential opportunities for IJPR's community. Based on a systematic literature review, seven propositions for future research were suggested. Furthermore, variables that are considered to be barriers and motivations to low-carbon operations management were organised into constructs as follows: (a) economic, (b) political/regulatory, (c) technological, (d) governance and (e) market.

Overall, some potential discussions emerged as a consequence of the seven propositions suggested, including methods to mitigate barriers to the adoption of low-carbon operations management practices and the development of capabilities to boost or implement motivators for the adoption of low-carbon operations management practices. These two issues should be analysed through the lens of Ability-Motivation-Opportunity theory, which argues that human resources management practices improve employees' capabilities and in turn increase organisational performance (Appelbaum 2000; Argote, McEvily, and Reagans 2003; Renwick, Redman, and Maguire 2013). Consequently, enhancing employees' capabilities may assist organisations in dealing with the governance barrier, for instance. Additionally, other potential discussions include the contribution and effectiveness of policies proposed in line with EMT in developing countries to encourage the adoption of low-carbon operations management practices, and the need to integrate decisions regarding operations management in the debate on business strategies and climate change. Thus, there are many opportunities for new research on this topic.

This article has limitations, such as potential errors in the cognitive process of the systematisation of the articles and the selection of keywords used to search on the SCOPUS database. The following section puts forward the findings which are believed to have implications for the IJPR community.

\subsection{Implications for the International Journal of Production Research community}

Literature reviews published in the IJPR can have an impact on the production research community (Ho et al. 2015; Dolgui, Ivanov, and Sokolov 2017; Pinho and Mendes 2017; Sodhi and Tang 2017). In this context, Sarkis and Zhu (2017) point out that the IJPR has been an essential vehicle for developing knowledge on sustainable production. More specifically, considering the topic of low-carbon operations, the journal has contributed in three main areas: (a) low-carbon manufacturing; (b) low-carbon logistics and supply chain; and (c) low carbon product development.

Regarding low-carbon manufacturing, selected IJPR contributions are as follows. Chen and Hao (2015) found that the carbon emissions tax imposed on high-efficiency firms should be greater than that imposed on low-efficiency firms competing within the same industry. Wang and Choi (2016) suggested that market-based characteristics of the cap-andtrade mechanism use economic benefits to motivate firms to adopt low-carbon technologies and environmental-friendly facilities to curb greenhouse gas emission. Liu et al. (2015) proposed optimisation models to determine the remanufacturing quantity that maximises total profits under three common carbon emission regulation policies. Dhavale and Sarkis (2015) developed quantitative models capable of integrating carbon market uncertainties into decisions on sustainable manufacturing investment. Liu and Huang (2014) examined carbon footprints within the context of production scheduling. Toptal, Özlü, and Konur (2014) analysed retailers' joint decisions on inventory replenishment and investment in carbon emission reduction under three carbon emission regulation policies. Lees, Evans, and Mareels (2012) proposed a model whereby stakeholders would see the portion of utilities consumption (or greenhouse gas impact) that did not directly contribute to saleable product and the impact of non-productive greenhouse gas emissions in a manufacturing environment, with the illustration of a packaging line in a brewery.

In terms of low-carbon supply chain and logistics management, Validi, Bhattacharya, and Byrne (2014) proposed an integrated low-carbon distribution system for the demand side of a product distribution supply chain. Du et al. (2015) analysed the impact of consumers' preference for low-carbon in the emission-concerned supply chain. Brandenburg 
(2015) suggested that decentralised supply chain configurations enable carbon emission reduction without affecting economic supply chain performance. Ni and Shu (2015) considered two models to examine how carbon capping, carbon emission cost rates and guaranteed service times affect the optimal safety stock placement for supply chains.

Low-carbon product development emerges as an area with potential for further study. One example in this field is Tang, Wang, and Ullah (2017), who shed light on the problem of product configuration by considering environmental and low-carbon emission issues. Thus, the contribution of the IJPR to the topic of low-carbon operations follows the same pattern as observed in Figure 7. Consequently, the main area that the IJPR's community could focus on is low-carbon product-related issues, including the life cycle of products from extraction to final disposal. It is believed that the proposed research agenda, as visualised in Figure 7, is useful for developing this area further, paving the way towards the consistent contribution of the IJPR to a more sustainable world.

This work is useful for teaching low-carbon operations management and can be used by production managers when dealing with the complexity of adopting low-carbon practices.

\section{Acknowledgement}

The authors acknowledge the National Council for Scientific and Technological Development (CNPq) for supporting this research (442121/2014-8).

\section{Disclosure statement}

No potential conflict of interest was reported by the authors.

\section{Funding}

This work was supported by the National Council for Scientific and Technological Development (CNPq) for supporting this research [442121/2014-8].

\section{References}

Aben, K., I. D. Hartley, and K. Wilkening. 2010. "Reducing Greenhouse Gas Emissions in the British Columbia Forest Industry 1990-2005." Technology in Society 32: 288-294. doi:10.1016/j.techsoc.2010.10.005.

Aguilera-Caracuel, J., N. E. Hurtado-Torres, and J. A. Aragón-Correa. 2012. "Does International Experience Help Firms to Be Green? A Knowledge-based View of How International Experience and Organisational Learning Influence Proactive Environmental Strategies." International Business Review 21: 847-861. doi:10.1016/j.ibusrev.2011.09.009.

Angell, L. C., and R. D. Klassen. 1999. "Integrating Environmental Issues into the Mainstream: An Agenda for Research in Operations Management." Journal of Operations Management 17: 575-598. doi:10.1016/S0272-6963(99)00006-6.

Annarelli, A., and F. Nonino. 2016. "Strategic and Operational Management of Organizational Resilience: Current State of Research and Future Directions." Omega 62: 1-18.

Appelbaum, E. 2000. Manufacturing Advantage: Why High-Performance Work Systems Pay off. Ithaca: Cornell University Press.

Argote, L., B. McEvily, and R. Reagans. 2003. "Managing Knowledge in Organizations: An Integrative Framework and Review of Emerging Themes." Management Science 49 (4): 571-582.

Barney, J. 1991. "Firm Resources and Sustained Competitive Advantage." Journal of Management 17: 99-120. doi:10.1177/ 014920639101700108.

Biesbroek, G. R., J. E. M. Klostermann, C. J. A. M. Termeer, and P. Kabat. 2013. "On the Nature of Barriers to Climate Change Adaptation.” Regional Environmental Change 13: 1119-1129. doi: 10.1007/s10113-013-0421-y

Boiral, O., J. F. Henri, and D. Talbot. 2012. "Modeling the Impacts of Corporate Commitment on Climate Change.” Business Strategy and the Environment 21: 495-516. doi:10.1002/bse.723.

Böttcher, C. F., and M. Müller. 2015. "Drivers, Practices and Outcomes of Low-Carbon Operations: Approaches of German Automotive Suppliers to Cutting Carbon Emissions." Business Strategy and the Environment 24: 477-498. doi:10.1002/bse.1832.

Brandenburg, M. 2015. "Low Carbon Supply Chain Configuration for a New Product - A Goal Programming Approach." International Journal of Production Research 53 (21): 6588-6610.

Burch, S. 2010. "In Pursuit of Resilient, Low Carbon Communities: An Examination of Barriers to Action in Three Canadian Cities." Energy Policy 38: 7575-7585. doi:10.1016/j.enpol.2009.06.070.

Busch, T., and V. H. Hoffmann. 2007. "Emerging Carbon Constraints for Corporate Risk Management." Ecological Economics 62: 518-528. doi:10.1016/j.ecolecon.2006.05.022.

Carlsson-Kanyama, A., H. Carlsen, and K.-H. Dreborg. 2013. "Barriers in Municipal Climate Change Adaptation: Results from Case Studies Using Backcasting.” Futures 49: 9-21. doi:10.1016/j.futures.2013.02.008. 
CDP (Carbon Disclosure Program). 2014. "Supply Chain Report 2013-2014.” https://www.cdp.net/CDPResults/CDP-Supply-ChainReport-2014.pdf

Chen, X., and G. Hao. 2015. "Sustainable Pricing and Production Policies for Two Competing Firms with Carbon Emissions Tax." International Journal of Production Research 53 (21): 6408-6420.

Chomaitong, S., and R. Perera. 2014. "Adoption of the Low Carbon Society Policy in Locally-Governed Urban Areas: Experience from Thai Municipalities.” Mitigation and Adaptation Strategies for Global Change 19: 1255-1275. doi:10.1007/s11027-0139472-0.

Chu, S. Y., and H. Schroeder. 2010. "Private Governance of Climate Change in Hong Kong: An Analysis of Drivers and Barriers to Corporate Action.” Asian Studies Review 34: 287-308. doi:10.1080/10357823.2010.507863.

Dangelico, R. M. 2016. "Green Product Innovation: Where We Are and Where We Are Going." Business Strategy and the Environment 25 (8): 560-576. doi:10.1002/bse.1886.

De Wolf, C., F. Pomponi, and A. Moncaster. 2017. "Measuring Embodied Carbon Dioxide Equivalent of Buildings: A Review and Critique of Current Industry Practice." Energy and Buildings 140: 68-80.

Dey, Asoke, Paul Laguardia, and Mahesh Srinivasan. 2011. "Building Sustainability in Logistics Operations: A Research Agenda." Management Research Review 34 (11): 1237-1259.

Dhavale, D., and J. Sarkis. 2015. "Integrating Carbon Market Uncertainties into a Sustainable Manufacturing Investment Decision: A Bayesian NPV Approach.” International Journal of Production Research 53 (23): 7104-7117.

Dilling, L., and E. Failey. 2013. "Managing Carbon in a Multiple Use World: The Implications of Land-use Decision Context for Carbon Management." Global Environmental Change 23: 291-300. doi:10.1016/j.gloenvcha.2012.10.012.

Dolgui, A., D. Ivanov, and B. Sokolov. 2017. "Ripple Effect in the Supply Chain: An Analysis and Recent Literature." International Journal of Production Research 1-17.

Du, S., J. Zhu, H. Jiao, and W. Ye. 2015. "Game-theoretical Analysis for Supply Chain with Consumer Preference to Low Carbon." International Journal of Production Research 53 (12): 3753-3768.

Du, Y., Q. Yi, C. Li, and L. Liao. 2015. "Life Cycle Oriented Low-carbon Operation Models of Machinery Manufacturing Industry." Journal of Cleaner Production 91: 145-157. doi:10.1016/j.jclepro.2014.12.028.

Dubey, R., R. Dubey, A. Gunasekaran, A. Gunasekaran, T. Papadopoulos, and T. Papadopoulos. 2017. "Green Supply Chain Management: Theoretical Framework and Further Research Directions.” Benchmarking: An International Journal 24 (1): $184-218$.

Dubey, R., A. Gunasekaran, S. J. Childe, T. Papadopoulos, B. Hazen, and D. Roubaud. 2017. "Examining Top Management Commitment to TQM Diffusion Using Institutional and Upper Echelon Theories." International Journal of Production Research 1-19.

Dulal, H. B., G. Brodnig, and K. U. Shah. 2011. "Capital Assets and Institutional Constraints to Implementation of Greenhouse Gas Mitigation Options in Agriculture." Mitigation and Adaptation Strategies for Global Change 16: 1-23. doi:10.1007/s11027010-9250-1.

Eisenack, K., S. C. Moser, E. Hoffmann, R. J. T. Klein, C. Oberlack, A. Pechan, M. Rotter, and C. J. A. M. Termeer. 2014. "Explaining and Overcoming Barriers to Climate Change Adaptation." Nature Climate Change 4: 867-872. doi:10.1038/nclimate2350.

Eisenhardt, K. M. 1989. "Building Theories from Case Study." Academy of Management Review 14: 532-550. doi:10.5465/ AMR.1989.4308385.

Er, A. C., A. P. J. Mol, and C. S. A. Van Koppen. 2012. "Ecological Modernization in Selected Malaysian Industrial Sectors: Political Modernization and Sector Variations." Journal of Cleaner Production 24: 66-75. doi:10.1016/j.jclepro.2011.11.042.

Fahimnia, B., J. Sarkis, and H. Davarzani. 2015. "Green Supply Chain Management: A Review and Bibliometric Analysis." International Journal of Production Economics 162: 101-114. doi:10.1016/j.ijpe.2015.01.003.

Fleiter, T., E. Gruber, W. Eichhammer, and E. Worrell. 2012. "The German Energy Audit Program for Firms - A Cost-effective Way to Improve Energy Efficiency?" Energy Efficiency 5: 447-469. doi:10.1007/s12053-012-9157-7.

Ford, J. D., T. Pearce, J. Prno, F. Duerden, L. B. Berrang Ford, M. Beaumier, and T. Smith. 2010. "Perceptions of Climate Change Risks in Primary Resource Use Industries: A Survey of the Canadian Mining Sector.” Regional Environmental Change 10: 6581. doi:10.1007/s10113-009-0094-8.

Forza, C. 2002. "Survey Research in Operations Management: A Process-based Perspective." International Journal of Operations \& Production Management 22: 152-194. doi:10.1108/01443570210414310.

Galbreath, J. 2014. "Climate Change Response: Evidence From the Margaret River Wine Region of Australia." Business Strategy and the Environment 23: 89-104. doi:10.1002/bse.1762.

Garbuzova, M., and R. Madlener. 2012. "Towards an Efficient and Low Carbon Economy Post-2012: Opportunities and Barriers for Foreign Companies in the Russian Energy Market." Mitigation and Adaptation Strategies for Global Change 17: $387-413$. doi:10.1007/s11027-011-9332-8.

Gasbarro, F., and J. Pinkse. 2016. "Corporate Adaptation Behaviour to Deal with Climate Change: The Influence of Firm-specific Interpretations of Physical Climate Impacts.” Corporate Social Responsibility and Environmental Management 23 (3): 179192. doi:10.1002/csr.1374.

Gasbarro, F., F. Rizzi, and M. Frey. 2014. "Adaptation Measures of Energy and Utility Companies to Cope with Water Scarcity Induced by Climate Change.” Business Strategy and the Environment 72: 54-72. doi:10.1002/bse.1857.

Giesekam, J., J. Barrett, P. Taylor, and A. Owen. 2014. "The Greenhouse Gas Emissions and Mitigation Options for Materials Used in UK Construction.” Energy and Buildings 78: 202-214. doi:10.1016/j.enbuild.2014.04.035. 
Gonzalez-Gonzalez, J. M., and C. Z. Ramirez. 2016. "Voluntary Carbon Disclosure by Spanish Companies: An Empirical Analysis." International Journal of Climate Change Strategies and Management 8: 57-79. doi:10.1108/17568690910955603.

Gouvea, R., S. Kassicieh, and M. J. R. Montoya. 2013. "Using the Quadruple Helix to Design Strategies for the Green Economy." Technological Forecasting and Social Change 80 (2): 221-230.

Grant, R. M. 1991. "The Resource-based Theory of Competitive Advantage: Implications for Strategy Formulation." California Management Review 33: 114-135. doi:10.1016/S0149-2063(99)00037-9.

Handler, R. M., D. R. Shonnard, P. Lautala, D. Abbas, and A. Srivastava. 2014. "Environmental Impacts of Roundwood Supply Chain Options in Michigan: Life-cycle Assessment of Harvest and Transport Stages." Journal of Cleaner Production 76: 6473. doi:10.1016/j.jclepro.2014.04.040.

Hart, S. L., and G. Dowell. 2011. "Invited Editorial: A Natural-resource-based View of the Firm: Fifteen Years after." Journal of Management 37: 1464-1479. doi:10.1177/0149206310390219.

He, Z., P. Chen, H. Liu, and Z. Guo. 2017. "Performance Measurement System and Strategies for Developing Low-carbon Logistics: A Case Study in China." Journal of Cleaner Production 156: 395-405.

Henriques, J., and J. Catarino. 2016. "Motivating towards Energy Efficiency in Small and Medium Enterprises." Journal of Cleaner Production 139: 42-50.

Herbohn, K., P. Dargusch, and J. Herbohn. 2012. "Climate Change Policy in Australia: Organisational Responses and Influences." Australian Accounting Review 22: 208-222. doi:10.1111/j.1835-2561.2012.00171.x.

Herrmann, J., and E. Guenther. 2017. "Exploring a Scale of Organizational Barriers for Enterprises' Climate Change Adaptation Strategies." Journal of Cleaner Production 160: 38-49.

Hitchcock, T. 2012. "Low Carbon and Green Supply Chains: The Legal Drivers and Commercial Pressures." Supply Chain Management: An International Journal 17: 98-101. doi:10.1108/13598541211212249.

Ho, W., T. Zheng, H. Yildiz, and S. Talluri. 2015. "Supply Chain Risk Management: A Literature Review." International Journal of Production Research 53 (16): 5031-5069.

IPCC (Intergovernmental Panel on Climate Change). 2014. “Climate Change 2014 Synthesis Report.” http://www.ipcc.ch/pdf/assess ment-report/ar5/syr/AR5_SYR_FINAL_All_Topics.pdf

Islam, S., and T. Olsen. 2014. "Truck-sharing Challenges for Hinterland Trucking Companies: A Case of the Empty Container Truck Trips Problem.” Business Process Management Journal 20: 290-334. doi:10.1108/BPMJ-03-2013-0042.

Jabbour, C. J. C. 2010. "In the Eye of the Storm: Exploring the Introduction of Environmental Issues in the Production Function in Brazilian Companies." International Journal of Production Research 48: 6315-6339. doi:10.1080/00207540802425401.

Jabbour, C. J. C. 2013. "Environmental Training in Organisations: From a Literature Review to a Framework for Future Research." Resources, Conservation and Recycling 74: 144-155. doi:10.1016/j.resconrec.2012.12.017.

Jaber, J. O., and S. D. Probert. 2001. " $\mathrm{CO}_{2}$ Mitigation Options and Barriers to Implementation in the Jordanian Energy-sector." Applied Energy 70: 1-15. doi:10.1016/S0306-2619(01)00024-1.

Jeswani, H. K., W. Wehrmeyer, and Y. Mulugetta. 2008. "How Warm is the Corporate Response to Climate Change? Evidence from Pakistan and the UK." Business Strategy and the Environment 17: 46-60. doi:10.1002/bse.569.

Jones, A. W. 2015. "Perceived Barriers and Policy Solutions in Clean Energy Infrastructure Investment." Journal of Cleaner Production 104: 297-304. doi:10.1016/j.jclepro.2015.05.072.

Jongh, D., and C. M. Möllmann. 2014. "Market Barriers for Voluntary Climate Change Mitigation in the South African Private Sector." South African Journal of Economic and Management Sciences 17: 639-652.

Kavouridis, K., and N. Koukouzas. 2008. "Coal and Sustainable Energy Supply Challenges and Barriers.” Energy Policy 36: 693703. doi:10.1016/j.enpol.2007.10.013.

Kragt, M. E., N. P. Dumbrell, and L. Blackmore. 2017. "Motivations and Barriers for Western Australian Broad-acre Farmers to Adopt Carbon Farming." Environmental Science \& Policy 73: 115-123.

Lah, O. 2015. "The Barriers to Low-carbon Land-Transport and Policies to Overcome Them." European Transport Research Review 7: 3-11. doi:10.1007/s12544-014-0151-3.

Lee, Su-Yol. 2012. "Corporate Carbon Strategies in Responding to Climate Change." Business Strategy and the Environment 21 (1): 33-48.

Lee, K.-H. 2015. "Drivers and Barriers to Energy Efficiency Management for Sustainable Development." Sustainable Development 23: 16-25. doi:10.1002/sd.1567.

Lee, Z. H., S. Sethupathi, K. T. Lee, S. Bhatia, and A. R. Mohamed. 2013. "An Overview on Global Warming in Southeast Asia: $\mathrm{CO}_{2}$ Emission Status, Efforts Done, and Barriers." Renewable and Sustainable Energy Reviews 28: 71-81. doi:10.1016/ j.rser.2013.07.055.

Lees, M., R. Evans, and I. Mareels. 2012. "Information Infrastructures for on-Line Measurement of Non-productive Greenhouse Gas Emissions in Manufacturing: Case of the Brewing Industry." International Journal of Production Research 50 (22): 65536573.

Leichenko, R., and J. A. Silva. 2014. "Climate Change and Poverty: Vulnerability, Impacts, and Alleviation Strategies." Wiley Interdisciplinary Reviews: Climate Change 5 (4): 539-556.

Lemieux, C. J., J. L. Thompson, J. Dawson, and R. M. Schuster. 2013. "Natural Resource Manager Perceptions of Agency Performance on Climate Change." Journal of Environmental Management 114: 178-189. doi:10.1016/j.jenvman.2012.09.014. 
Li, J., X. Liang, T. Cockerill, J. Gibbins, and D. Reiner. 2012. "Opportunities and Barriers for Implementing $\mathrm{CO}_{2} \mathrm{Capture}^{\mathrm{Ready}}$ Designs: A Case Study of Stakeholder Perceptions in Guangdong, China." Energy Policy 45: 243-251. doi:10.1016/j.enpol.2012.02.025.

Liu, Y. 2012. "An Empirical Research of Awareness, Behavior and Barriers to Enact Carbon Management of Industrial Firms in China." Science of the Total Environment 425: 1-8. doi:10.1016/j.scitotenv.2012.02.077.

Liu, Y. 2014. "Barriers to the Adoption of Low Carbon Production: A Multiple-case Study of Chinese Industrial Firms." Energy Policy 67: 412-421. doi:10.1016/j.enpol.2013.12.022.

Liu, C. H., and D. H. Huang. 2014. "Reduction of Power Consumption and Carbon Footprints by Applying Multi-objective Optimisation via Genetic Algorithms." International Journal of Production Research 52 (2): 337-352.

Liu, L. Q., C. X. Liu, and Z. Y. Sun. 2011. "A Survey of China's Low-carbon Application Practice - Opportunity Goes with Challenge.” Renewable and Sustainable Energy Reviews 15: 2895-2903. doi:10.1016/j.rser.2011.02.034.

Liu, B., M. Holmbom, A. Segerstedt, and W. Chen. 2015. "Effects of Carbon Emission Regulations on Remanufacturing Decisions with Limited Information of Demand Distribution." International Journal of Production Research 53 (2): $532-548$.

Lo, S. F. 2010. "Global Warming Action of Taiwan's Semiconductor/TFT-LCD Industries: How Does Voluntary Agreement Work in the IT Industry?” Technology in Society 32: 249-254. doi:10.1016/j.techsoc.2010.07.007.

Long, T. B., V. Blok, and I. Coninx. 2016. "Barriers to the Adoption and Diffusion of Technological Innovations for Climate-smart Agriculture in Europe: Evidence from the Netherlands, France, Switzerland and Italy." Journal of Cleaner Production 112: 921.

Luo, L., Q. Tang, and Y. Lan. 2013. "Comparison of Propensity for Carbon Disclosure between Developing and Developed Countries." Journal of Accounting Research 26: 6-34. doi:10.1108/ARJ-04-2012-0024.

Mariano, E. B., V. A. Sobreiro, and D. A. D. N. Rebelatto. 2015. "Human Development and Data Envelopment Analysis: A Structured Literature Review.” Omega 54: 33-49. doi:10.1016/j.omega.2015.01.002.

Masud, M. M., M. N. Azam, M. Mohiuddin, H. Banna, R. Akhtar, A. F. Alam, and H. Begum. 2017. "Adaptation Barriers and Strategies Towards Climate Change: Challenges in the Agricultural Sector." Journal of Cleaner Production 156: 698-706.

McKinsey. 2012. "The Business of Sustainability." McKinsey on Sustainability \& Resource Productivity. 96-105. http:/www.mckin sey.com/ /media/mckinsey/dotcom/client_service/sustainability/pdfs/mck\%20on\%20srp/srp_11_biz\%20sustainability.ashx.

Meath, C., M. Linnenluecke, and A. Griffiths. 2016. "Barriers and Motivators to the Adoption of Energy Savings Measures for Small-and Medium-sized Enterprises (SMEs): The Case of the Climate Smart Business Cluster Program.” Journal of Cleaner Production 112: 3597-3604.

Meyers, S., B. Schmitt, M. Chester-Jones, and B. Sturm. 2016. "Energy Efficiency, Carbon Emissions, and Measures towards Their Improvement in the Food and Beverage Sector for Six European Countries." Energy 104: 266-283.

Moser, S. C., and J. A. Ekstrom. 2010. "A Framework to Diagnose Barriers to Climate Change Adaptation." Proceedings of the National Academy of Sciences. 107 (51): 22026-22031.

Nakićenović, N. 1996. "Decarbonisation: Doing More with Less." Technological Forecasting and Social Change 51 (1): 1-17.

Ng, S. T., M. Skitmore, and J. N. H. Cheung. 2013. "Organisational Obstacles to Reducing Carbon Emissions in Hong Kong." Habitat International 40: 119-126. doi:10.1016/j.habitatint.2013.03.004.

Ni, W., and J. Shu. 2015. "Trade-off Between Service Time and Carbon Emissions for Safety Stock Placement in Multi-echelon Supply Chains." International Journal of Production Research 53 (22): 6701-6718.

Norlund, E. K., and I. Gribkovskaia. 2013. "Reducing Emissions through Speed Optimization in Supply Vessel Operations." Transportation Research Part D: Transport and Environment 23: 105-113. doi:10.1016/j.trd.2013.04.007.

Okereke, C. 2007. "An Exploration of Motivations, Drivers and Barriers to Carbon Management." European Management Journal 25: 475-486. doi:10.1016/j.emj.2007.08.002.

Okereke, C., and K. Küng. 2013. "Climate Policy and Business Climate Strategies: EU Cement Companies' Response to Climate Change and Barriers against Action." Management of Environmental Quality: An International Journal 24: $286-310$. doi:10.1108/14777831311322622.

Pålsson, H., and G. Kovács. 2014. "Reducing Transportation Emissions" International Journal of Physical Distribution \& Logistics Management 44: 283-304. doi:10.1108/IJPDLM-09-2012-0293.

Pan, S., E. Ballot, and F. Fontane. 2013. "The Reduction of Greenhouse Gas Emissions from Freight Transport by Pooling Supply Chains." International Journal of Production Economics 143: 86-94. doi:10.1016/j.ijpe.2010.10.023.

Pasquini, L., R. M. Cowling, and G. Ziervogel. 2013. "Facing the Heat: Barriers to Mainstreaming Climate Change Adaptation in Local Government in the Western Cape Province, South Africa." Habitat International 40: 225-232. doi:10.1016/j.habitatint.2013.05.003.

Pegels, A. 2010. "Renewable Energy in South Africa: Potentials, Barriers and Options for Support." Energy Policy 38: $4945-4954$. doi:10.1016/j.enpol.2010.03.077.

Peng, J., J. Sun, and R. Luo. 2015. "Corporate Voluntary Carbon Information Disclosure: Evidence from China's Listed Companies." The World Economy 38: 91-109. doi:10.1111/twec.12187.

St-Laurent, G. P., S. Hagerman, and G. Hoberg. 2017. "Barriers to the Development of Forest Carbon Offsetting: Insights from British Columbia, Canada." Journal of Environmental Management 203: 208-217. 
Pinho, C., and L. Mendes. 2017. "IT in Lean-based Manufacturing Industries: Systematic Literature Review and Research Issues." International Journal of Production Research 1-17.

Pitt, D., and J. Randolph. 2009. "Identifying Obstacles to Community Climate Protection Planning." Environment and Planning C: Government and Policy 27: 841-857. doi:10.1068/c0871.

Plambeck, E. L. 2012. "Reducing Greenhouse Gas Emissions Through Operations and Supply Chain Management." Energy Economics 34: S64-S74. doi:10.1016/j.eneco.2012.08.031.

Polzin, F. 2017. "Mobilising Private Finance for Low-carbon Innovation - A Systematic Review of Barriers and Solutions." Renewable and Sustainable Energy Reviews 77: 525-535.

Renwick, D. W., T. Redman, and S. Maguire. 2013. "Green Human Resource Management: A Review and Research Agenda.” International Journal of Management Reviews 15 (1): 1-14.

Reyers, M., D. Gouws, and J. Blignaut. 2011. "An Exploratory Study of Motivations Driving Corporate Investment in Voluntary Climate Change Mitigation in South Africa." South African Journal of Economic and Management Sciences 14: 92-108.

Rosen, R. A., and E. Guenther. 2015. "The Economics of Mitigating Climate Change: What Can We Know?" Technological Forecasting and Social Change 91: 93-106. doi:10.1016/j.techfore.2014.01.013.

Salon, D., S. Murphy, and G.-C. Sciara. 2014. "Local Climate Action: Motives, Enabling Factors and Barriers.” Carbon Management 5: 67-79. doi:10.4155/cmt.13.81.

Santos, G. 2017. "Road Transport and $\mathrm{CO}_{2}$ Emissions: What Are the Challenges?" Transport Policy 59: 71-74.

Sarkis, J., and A. Rasheed. 1995. "Greening the Manufacturing Function.” Business Horizons 38: 17-27. doi:10.1016/0007-6813(95) 90032-2.

Sarkis, J., and Q. Zhu. 2017. "Environmental Sustainability and Production: Taking the Road Less Traveled." International Journal of Production Research 1-17.

Sarkis, J., Q. Zhu, and K. H. Lai. 2011. “An Organizational Theoretic Review of Green Supply Chain Management Literature.” International Journal of Production Economics 130: 1-15. doi:10.1016/j.ijpe.2010.11.010.

Sentance, A. 2009. "Developing Transport Infrastructure for the Low Carbon Society." Oxford Review of Economic Policy 25: 391410. doi:10.1093/oxrep/grp026.

Sodhi, M. S., and C. S. Tang. 2017. "Corporate Social Sustainability in Supply Chains: A Thematic Analysis of the Literature.” International Journal of Production Research 1-20.

Sullivan, R. 2009. "The Management of Greenhouse Gas Emissions in Large European Companies." Corporate Social Responsibility and Environmental Management 16: 301-309. doi:10.1002/csr.187.

Tait, E., R. Laing, and D. Gray. 2014. "Governance and Policy Challenges of Implementing Urban Low-carbon Transport Initiatives." Local Economy 29: 129-140. doi:10.1177/0269094214521980.

Tang, Christopher S., and Sean Zhou. 2012. "Research Advances in Environmentally and Socially Sustainable Operations." European Journal of Operational Research 223 (3): 585-594.

Tang, D., Q. Wang, and I. Ullah. 2017. "Optimisation of Product Configuration in Consideration of Customer Satisfaction and Low Carbon.” International Journal of Production Research 55 (12): 3349-3373.

Toptal, A., H. Özlü, and D. Konur. 2014. "Joint Decisions on Inventory Replenishment and Emission Reduction Investment under Different Emission Regulations.” International Journal of Production Research 52 (1): 243-269.

Touboulic, A., and H. Walker. 2015. "Theories in Sustainable Supply Chain Management: A Structured Literature Review." International Journal of Physical Distribution \& Logistics Management 45: 16-42. doi:10.1108/IJPDLM-05-2013-0106.

Tranfield, D., D. Denyer, and P. Smart. 2003. "Towards a Methodology for Developing Evidence-Informed Management Knowledge by Means of Systematic Review.” British Journal of Management 14: 207-222. doi:10.1111/1467-8551.00375.

UNFCCC (United Nations Framework Convention on Climate Change). 2015a. http://unfecc.int/meetings/items/6240.php

UNFCCC (United Nations Framework Convention on Climate Change). 2015b. "More Details About the Agreement." http:// www.cop21.gouv.fr/en/more-details-about-the-agreement/

Urge-Vorsatz, D., A. Novikova, S. Köppel, and B. Boza-Kiss. 2009. "Bottom-up Assessment of Potentials and Costs of $\mathrm{CO}_{2}$ Emission Mitigation in the Buildings Sector: Insights into the Missing Elements." Energy Efficiency 2: 293-316. doi:10.1007/ s12053-009-9051-0.

Validi, S., A. Bhattacharya, and P. J. Byrne. 2014. "Integrated Low-carbon Distribution System for the Demand Side of a Product Distribution Supply Chain: A DoE-guided MOPSO Optimiser-based Solution Approach." International Journal of Production Research 52 (10): 3074-3096.

Wang, X. J., and S. H. Choi. 2016. "Impacts of Carbon Emission Reduction Mechanisms on Uncertain Make-to-order Manufacturing." International Journal of Production Research 54 (11): 3311-3328.

WBCSD (World Business Council for Sustainable Development). 2008. "Sustainable Consumption Facts and Trends." http://www. wbcsd.org/pages/edocument/edocumentdetails.aspx?id=142

Winn, M., M. Kirchgeorg, A. Griffiths, M. K. Linnenluecke, and E. Günther. 2011. "Impacts from Climate Change on Organizations: A Conceptual Foundation." Business Strategy and the Environment 20 (3): 157-173.

Wong, P. S. P., S. T. T. Ng, and M. Shahidi. 2013. "Towards Understanding the Contractor's Response to Carbon Reduction Policies in the Construction Projects." International Journal of Project Management 31: 1042-1056. doi:10.1016/j.ijproman.2012.11.004. 
Yi, H., R. C. Feiock, and F. S. Berry. 2017. "Overcoming Collective Action Barriers to Energy Sustainability: A Longitudinal Study of Climate Protection Accord Adoption by Local Governments.” Renewable and Sustainable Energy Reviews 79: $339-346$.

Zhang, B., and Z. Wang. 2014. "Inter-firm Collaborations on Carbon Emission Reduction within Industrial Chains in China: Practices, Drivers and Effects on Firms' Performances.” Energy Economics 42: 115-131. doi:10.1016/j.eneco.2013.12.006.

Zhu, Q., and Y. Geng. 2013. "Drivers and Barriers of Extended Supply Chain Practices for Energy Saving and Emission Reduction among Chinese Manufacturers.” Journal of Cleaner Production 40: 6-12. doi:10.1016/j.jclepro.2010.09.017.

Zhu, Q., Y. Geng, J. Sarkis, and K. Lai. 2011. "Evaluating Green Supply Chain Management among Chinese Manufacturers from the Ecological Modernization Perspective." Transportation Research Part E: Logistics and Transportation Review 47: 808-821. doi:10.1016/j.tre.2010.09.013. 